\title{
Z SITNICY PRZEZ NEMSYNO, ROSUMBERK, ROZEMBARK DO ROŻNOWIC
}

Na stronie internetowej encyklopedii Wikipeda.org czytamy:

Sitnica została założona przez króla Kazimierza Wielkiego, który w dokumencie spisanym na Zamku królewskim w Krakowie 30 sierpnia [września!] 1351 zezwolił Janowi z Biecza na lokację wsi nad rzeką Sczitnicza, na prawie niemieckim, zwanym magdeburskim.

Takie stanowisko zajmują współcześni autorzy, interesujący się lokalną historią, a także Franciszek Sikora autora hasła „Biecz” w: Stowniku historycznogeograficznym województwa krakowskiego w średniowieczu ${ }^{1}$. Ani królewski dokument, wydany przez Franciszka Piekosińskiego, ani poprzedzający go regest, nie mówią o lokacji wsi Sitnica² ${ }^{2}$. Ta błędna interpretacja treści dokumentu i jego

* Ks. Marian Brudzisz CSsR - dr historii Kościoła; emerytowany profesor Wyższego Seminarium Duchownego Redemptorystów i dyrektor Biblioteki Akademii Teologii Moralnej - Accademia Alfonsiana w Rzymie; e-mail: marianbrudzisz@gmail.com

${ }^{1}$ W. Pachowicz, Ksiądz tukasz Forystek, Tarnów 1992, s. 8-10; tenże, Rożnowice, Szkice $z$ dziejów parafii, Rzepiennik Suchy 2002; tenże, Bractwo św. Anny w Rozembarku, Gromnik 1954; na str. 174-200 są: Dzieje parafii Rozembark do roku 1638 (faktycznie do 1767 r.); J. Mruk, Kościót parafialny pw. św. Andrzeja i Anny w Rożnowicach. Studium historyczno-zabytkowe obiektu. Praca magisterska, Rzeszów 2008, s. 8-17; A. Mruk, Ludność parafii Rożnowice w latach 1918-1939, Rzeszów 2009, s. 5-24. - Interesująca jest praca dyplomowa Emilii Kozieł, Monografia Rożnowic, napisana w 1965 r. Autor dysponuje częściowym odpisem tego tekstu w maszynopisie. Na stronach 22-24 autorka pracy omawia ,przeszłość historyczną” Rożnowic w wiekach XIII-XIV, dobrze udokumentowaną. Ale z początkami Rożnowic/Rozembarku i Nemsynem miała takie same problemy jak inni; Cz. Dutka, Z dziejów Sitnicy, w: Sitnica wczoraj, dziś, jutro... Ku pamięci 660 lat, 120-lecia szkoły i Roku Kolbiańskiego. Sitnica 2011, s. 7-10; tenże, Echo minionych dni Rzepiennika, Rzepiennik Suchy 1993, s.11; C. Juruś, W gminie Biecz, Sitnica-legendy i fakty, Racławice 2016, s. 9-10; taż, Rożnowicko - racławickie legendy i fakty, Racławice 2009, s. 37-38.

${ }^{2}$ Kodeks Dyplomatyczny Małopolski 1333-1386, T. III (Monumenta Medii Aevi Historica Res Gestas Poloniae Illustrantia. T. X), ed. Franciszek Piekosiński, Cracoviae 1887, s. XI-XII, s. 81-82; F. Sikora, „Biecz”, w: Stownik historyczno-geograficznym województwa krakowskiego w średnio- 
regestu od dawna budziła moje zdziwienie. Częścią składową tej parafii, od początku jej powstania była i jest wieś Sitnica. Ten temat podjęli inni, powtarzając błędną interpretację przywileju królewskiego. Tę interpretację przyjął także F. Sikora, autor hasła Biecz. Lektura nowszych publikacji o Bieczu, Binarowej, Rożnowicach, Rzepiennikach i Sitnicy, głosząca, że król Kazimierz Wielki założył wieś Sitnicę przywilejem lokacyjnym z 30 września 1351 r., skłoniła mnie do zajęcia się tym dokumentem.

\section{Przywilej lokacyjny z 30 września 1351 r.}

Regest. Kazimirus rex Poloniae Ioanni de Biecz locandi villam ad fluvium Sietnicza iure Teutonico Magdeburgensi dat potestatem - Kazimierz, król Polski, daje Janowi z Biecza władzę zatożenia wsi na prawie niemieckim, magdeburskim, przy rzece Sietnica.

Wersja łacińska, znajduje się w: Kodeks dyplomatyczny Małopolski. T. III (Monumenta Medii Aevi Historica Res Gestas Poloniae Illustrantia. T. X). Ed. Franciszek Piekosiński, Cracoviae 1887, s. XI-XII, 81-82:

\section{1, die 30. M[ensis] Septembris, Cracoviae.}

In nomine Domini amen. Quod magnifica regum maiestas facere decreuit maxime ad vtilitatem regni sui, debet esse firmum et stabile, roburque perpetue firmitatis obtinere. Proinde nos Kazimirus Dei gracia rex Poloniae, notum facimus uniuersis tam presentibus, quam futuris, hanc litteram inspecturis, quod cupientes utilitates regni nostri peramplius ampliare de siluis, de quibus nobis nulla penitus utilitas proueniebat, discreto Iohanni de Byecz damus villam in fluvio dicto Sczitnicza iure Theutonico, (quod) Maydburgense dicitur, locandi omnimodam potestatem. Que villa habebit infra limites sexaginta mansos, in qua villa racione locacionis predicto Iohanni et posteris ipsius damus sculteciam perpetuo et iure hereditario tenendam, habendam, possidendam, donandam, vendendam, commutandam, pro suaque et suorum posterorum voluntate convertendam. Cui sculteto et sue legitime posteritati damus perpetuo quatuor mansos liberos, eciam damus pro ecclesia unum mansum et alium pro pellendo grege, quod scothnicza vocatur, more predicto Maymburgensi mesuraturos, molendinumque postest facere in fluuio predicto infra limites dicte ville libere. Dicto sculteto et ipsius successoribus damus piscatorium, tabernam liberam, macellum piscatorium, tabernam liberam, macellum liberum carnium, panum, leguminum, cameram sutorum, piscinam liberam in villa vel extra villam, cui scutetto et posteris ipsius licebit piscari pisces libere, quatuor ortos liberos; item damus sibi et suis posteris perpetuos tercium denarium de iudicio in penis tam magnis quam paruis, duobus dumtaxat pro nobis reseruatis. Et vt dicta villa eo cicius locari possit, omnibus et singulis kmethonibus, qui in ea villa locabuntur, a data presencium ad viginti annos a solucione census et a servuicio damus et elargimur omnimodam libertatem, qua

wieczu, cz. I., opr. Z. Leszczyńska-Skrętowa, F. Sikora, Wrocław 1980, s. 82: „Kazimierz Wielki powierzył mieszczaninowi bieckiemu, Janowi, lokację wsi nad rzeką na prawach magdeburskich [Sietniczy]!". 
elapsa tunc kmethones singulis annis perpetuo semper in festo beati Martini de quolibet manso per octo scotos grossorum soluent et pro decima debebunt per fertonem. Preterea ad tria iudicia magna, que ter in anno fieri consueuerunt, nostro nuncio, quem ad hoc mittemus, unum prandium scultetus et duo kmethones dabunt, vel pro quolibet prandio per sex scotos solvent. Remouemus namque omnia iura Polonicalia, angarias et perangarias qualescumque, ita vt sculteti dicte ville non alias, nisi in iudicio nostro Teutonicali iure Teutonico predicto, dum tamen per nostram litteram fuerint citati, respondebunt, kmethones vero coram scultetis predicte ville iure eodem respondere teneantur. In causis autem criminalibus et alii quibuscumque paruis vel magnis predicto sculteto et suis successoribus iuxta ipsum ius Teutonicum in villa sepedicta et infra limites ipsius (iudicandi), condemnandi, puniendi damus et tribuimus omnimodam facultatem. Excipimus tamen, quod scultetus et posteri ipsius ad quamlibet expedicionem generalem seruire (in) equo competenti tenebitur. In cuius rei testimonium nostrum sigillum duximus presentibus appendendum. Datum Cracouie incrastino beati Michaelis, anno Domini millesimo trecentesimo quinquagesimo primo. Presentibus iis testibus: Hermano procuratore, Vilczcone Sandomiriensi catellano, Floriano cancellano Lanciciensi et aliis multis.

Z potwierdzenia króla Zygmunta I dtto Cracoviae Iunii 1509, oblatowanego w księdze metryki 23, fol. 635.

\section{Thumaczenie polskie}

Regest: Kazimierz, król Polski, daje Janowi z Biecza pełną władzę założenia wsi przy rzece Sietnica na prawie niemieckim, zwanym magdeburskim.

Przywilej Kazimierza Wielkiego, podpisany 30 września 1351 r. w Krakowie.

W imię Boga. Amen. To, co wspaniały majestat królewski postanowił uczynić dla pożytku państwa powinno być wykonane i stale oraz wiecznie obwiązywać. Zatem, My, Kazimierz, król Polski, informujemy wszystkich, tak tu obecnych, jak i potomnych, którzy to pismo będą studiować, że pragniemy, aby nasze królestwo jak najlepiej korzystało z lasów, z których dotąd nie było należytego pożytku. Dlatego zaufanemu, Janowi z Biecza ${ }^{3}$ dajemy pełną władzę, aby przy rzece zwa-

${ }^{3}$ Biecz - jedno z najstarszych miast polskich, przeżywające swój rozkwit od XIII w. do połowy XVII w. Autor nie zajmuje się jego historią, ponieważ wykracza poza podjęty temat. Interesujących się jego historią i jego znaczeniem w administracji państwowej oraz kulturze odsyłam do: Miasto Biecz. Bibliografia (wybór), oprac. I. Górny, Kraków 2001; F. Sikora, Biecz, w: Stownik historyczno-geograficzny województwa krakowskiego w Średniowieczu, oprac. Z. Leszczyńska-Skrętowa, F. Sikora, Wrocław 1980, Cz. I, s. 72-82; Biecz w: Stownik geograficzny Królestwa Polskiego i innych krajów słowiańskich, T. 1, kol. 205-206; W. Fusek. Biecz i dawna ziemia biecka na tle swych legend, bajek. Przesądów i zwyczajów, Biecz 1939; Nad rzeką Ropą. Z dziejów Biecza, Gorlic i okolicy, red J. Barut, S. Motyka, T. Ślawski, Kraków 1963; Materiaty do historii miasta Biecza (1361-1632), oprac. F. Bujak, Kraków 1914; A. Żaki, Biecz i kasztelania biecka w zaraniu dziejów. Szlak archeologiczno-historyczny, w: Biecz. Studia historyczne, red. R. Kaleta, Wrocław 1963, s. 34-63; R. Kaleta, Zamek w Bieczu, w: Biecz. Studia historyczne, red. R. Kaleta, Wroctaw 1963, s. 82-115; A. Kłodziński, Biecz na przełomie XIII/XIV w, w: Biecz. Studia historyczne, red. R. Ka- 
nej Sczitnicza! [Szczytnica], lokował wieś na prawie niemieckim, nazywanym magdeburskim. Ta wieś nie może posiadać więcej łanów jak 60, a wymienionemu Janowi i jego potomkom, $\mathrm{z}$ tytułu jej zorganizowania, dajemy sołectwo w wieczyste posiadanie, z prawem dziedziczenia, darowania, sprzedania, wynajmu i zamiany, według swojego uznania i swoich potomków. Ponadto, temu sołtysowi i jego prawowitym potomkom, dajemy na zawsze cztery łany wolne od opłat, dla kościoła jeden łan [uprawny], a drugi na pastwisko, nazywane skotnicą ${ }^{4}$; [łany mają być] wymierzone zgodnie $\mathrm{z}$ prawem magdeburskim; [dajemy również] władzę zbudowania młyna na wymienionej rzece, ale w granicach tejże wsi. Sołtysowi i jego następcom dajemy targ rybny, wolną karczmę, ubojnię, piekarnię, targ dla warzyw strączkowych, lokal szewski, staw rybny we wiosce lub poza nią, w której sołtys lub jego następcy będą mogli swobodnie łowić ryby w cztery dowolne poranki. A dla siebie, i dla naszych następców, zastrzegamy co trzeciego denara z tytułu tak wielkich jak i małych sądów, a przynajmniej dwa zastrzegamy dla nas. Ale, aby ta wieś mogła być szybko zorganizowana, zwalniamy wszystkich kmieciów i każdego z osobna, którzy w niej się osiedlą, od czynszu i różnych posług na 20 lat od daty podpisania tego dokumentu; po upływie tych lat kmiecie będą zobowiązani do płacenia w dzień świętego Marcina [11 XI] ośmiu szkojców groszy od każdego łanu, a jako dziesięcinę winni będą dawać jednego fertona. Ponadto, delegatowi, jakiego wyślemy na trzy sesje wielkich sądów, które zazwyczaj odbywają się trzy razy w roku, jeden obiad zapłaci [zorganizuje] sołtys, a kmiecie

leta, Wroctaw 1963, s.116-123; J. Barut, Dawna ziemia biecka i jej stolica, w: Biecz. Studia historyczne, red. R. Kaleta, Wrocław 1963, s. 124-151; T. Ślawski, Biecz. Na Jubileusz 2000-lecia, Biecz 1999-2000; tenże, Szkice historyczne, Biecz 2002; tenże, Biecz i okolice Biecza, Biecz 2005; tenże, Biecz i dawna Ziemia Biecka, w: Nad rzeka Ropa, s. 9-83; S. Kuraś, Osadnictwo i zagadnienia wiejskie w Gorlickiem do połowy XVI w., w: Nad rzeka Ropa, [Cz. 3], Kraków 1968, s. 61-91; F. Kiryk, Z dziejów miast zachodniej części ziemi bieckiej do 1520, w: Nad rzeka Ropa,[Cz. 3], Kraków 1968, s. 155-2000. Zob. Cz. Dutka, Echo minionych dni Rzepiennika. Rzepiennik Suchy 1993, s. 9-14 passim; tenże, Z dziejów Sitnicy, w: Sitnica wczoraj, dziś, jutro... Ku pamięci 660 lat, 120-lecia szkoty i Roku Kolbiańskiego, Sitnica 2011, s. 7-10. Pomijam prace poświęcone czasom nowożytnym.

${ }^{4}$ Tekst łaciński: ,eciam damus pro ecclesia unum mansum et alium pro pellendo grege, quod scothnicza vocatur” - może być tłumaczony: „dajemy także dla kościoła jeden łan, a drugi na pastwisko, nazywane skotniczą”, albo: „i drugi na pastwisko plebańskie”. W dokumencie powizytacyjnym parafii w 1595 r. napisano: uposażenie parafii stanowią dwa łany, zob. Archiwum Kurii Metropolitarnej w Krakowie, Wizytacje, nr 4, Acta visitationis interioris 1595, s. 150-151v: „Pro dote habet agri lancos duo" - [kościół] jako uposażenie posiada dwa łany; takie samo uposażenie notują wizytacje w 1602 r. i 1767 r. Ale w sprawozdaniu z wizytacji z 1767 r. napisano także, że jeden łan ciągnie się od kościoła aż do granicy z Kwiatoniowicami, a drugi łan od kościoła do granicy z Ołpinami. W dokumencie z 1767 r. dodano, że łan południowy leży między sołtysówką Jana Kamińskiego z jednej strony, a Kaczmarzówką z drugiej; łan północny między polami Wojciecha Miki i tak zwaną Pierzówką (zob. Archiwum Archidiecezjalne w Przemyślu, nr 293, Acta visitationis decanatus Biecensis ex anno 1767 s. 161 i Ośrodek ABMK, mf 270). - Z. Kramarczyk napisał, że król Kazimierz Wielki w wioskach zakładanych na podstawie jego przywileju dla kościoła przeznaczał zasadniczo jeden łan, czasem dwa, a rzadko więcej. Zob. Z. Kaczmarczyk, Monarchia Kazimierza Wielkiego. T. 2. Organizacja Kościoła, sztuka i nauka. Poznań 1946, s. 89. 
dwa obiady, albo za każdy obiad zapłacą po sześć szkojców5 ${ }^{5}$ Równocześnie odwołujemy całe prawodawstwo polskie, a więc jakiekolwiek podwody i przewozy, a sołtysi tej wsi odpowiedzialni będą przed naszym trybunałem prawa niemieckiego i zgodnie $\mathrm{z}$ prawem niemieckim, ale tylko wtenczas, gdy zostaną wezwani naszym pismem, natomiast kmiecie odpowiadać będą przed sołtysem zgodnie z prawem niemieckim. W sprawach kryminalnych i innych jakichkolwiek, małych czy dużych, postanawiamy, że sołtys tej wsi, często wymienianej, i jego następcy, będą mieli prawo orzekania, skazywania i karania, ale tylko w granicach tej wsi. Robimy jednak wyjątek [dla zachowania prawa polskiego], postanawiając, że sołtys, i jego następcy, zgodnie z prawem polskim, będzie zobowiązany uczestniczyć w każdej generalnej ekspedycji, na koniu należycie wyposażonym.

Dokument ten sporządzono w Krakowie, nazajutrz po świętym Michale, w Roku Pańskim tysiąc trzysta pięćdziesiątym pierwszym [30. 09. 1351], w obecności następujących świadków: Hermana prokuratora, Wilczka kasztelana sandomierskiego, Floriana kanclerza łowickiego i licznych innych”.

\section{Analiza dokumentu}

Najpierw przedmiotem analizy będzie regest, streszczenie dokumentu (przywileju) królewskiego, sporządzonego przez wydawcę, Franciszka Piekosińskiego:

Kazimirus rex Poloniae Ioanni de Biecz locandi villam ad fluvium Sietnicza iure Teutonico Magdeburgensi dat potestatem, czyli: Kazimierz, król Polski, daje Janowi z Biecza władzę założenia wsi na prawie niemieckim, magdeburskim, przy rzece Sietnica ${ }^{6}$.

Pozornie tekst regestu jest poprawny: „Jan z Biecza otrzymal władzę zalożenia wsi przy rzece Sczitnicza", ale jego sformułowanie przez wydawcę, F. Piekosińskiego, jest oparte tylko na początku dokumentu królewskiego. Za autorem Regestu poszli niektórzy autorzy prac historycznych, przewodników i informatorów i traktowali ten przywilej lokacyjny jako upoważnienie króla Kazimierza Wielkiego, dane Janowi z Biecza do założenia nowej wsi, Sitnicy, na prawie

${ }^{5} \mathrm{~W}$ sprawie terminów: mansus, włóka i łan, korzystałem z prac: J. Szewczyk, Włóka. Pojęcie i termin na tle innych średniowiecznych jednostek pomiaru ziemi, Warszawa 1968 i F. Piekosiński, O łanach w Polsce wieków średnich, Kraków 1887. „Łan” = dawna jednostka podziału (roli uprawnej); łan chełmiński = 17,995 ha = 30 morgów; łan frankoński, magdeburski = 24, 2 ha= 48 morgów. Mansus - to miara ziemi, równa włóce i łanowi; ale też małe gospodarstwo wiejskie; „Scot” - Szkot - szkojc, to jednostka wagi; „Ferton” = 1/4 grzywny, czyli 12 groszy”; „Scothnicza” = Skotnica wspólne pastwisko, droga, którą wypędzono do niego stado bydła albo jedno i drugie; ,wygon”.

${ }^{6}$ Kodeks dyplomatyczny matopolski 1333-1386, T. III (Monumenta Medii Aevi HistoricaRes Gestas Poloniae Illustrantia, T. X), ed. Piekosiński Franciszek, Kraków 1874, s. 81. - Dokument, który zostaje poddany analizie, w swojej strukturze i treści, jest bardzo podobny dokumentu lokacji Binarowej, wystawionego 23 czerwca 1348 r., trzy lata wcześniej. Obydwa były sporządzone dla lokacji „wsi przy rzece S(cz)itniczy”. Wielkość ta sama, po 60 łanów, uposażenie bardzo podobne, ale sołtys rosumberskiej otrzymał 4 łany, binarowskiej 6 . Obydwie były przenoszone z prawa polskiego na magdeburskie. Zob. A. Januszek-Sieradzka, Binarowa $w$ XIV-XVI stuleciu, w: Binarowa. Studia i materiały z dziejów parafii i sanktuarium, red. W. Bielak, B. Walicki, S. Zych, Kolbuszowa 2011, s. 9-15. 
magdeburskim. Przez dodanie nazwy wsi: Sitnica, powiększył się błąd utrudniający poprawne zrozumienie Regestu królewskiego przywileju.

Dokument królewski nie mówi o upoważnieniu Jana z Biecza do założenia wsi Sitnica „przy rzece Sczitnicza”. Oto tekst:

Nos Kazimirus Dei gracia rex Poloniae, notum facimus universis, tam presentibus, quam futuris, hanc litteram inspecturis, quod cupientes utilitates regni nostri peramplius ampliare de siluis, de quibus nobis nulla penitus utilitas proveniebat, discreto Iohanni de Byecz damus villam in fluvio dicto Sczitnicza iure Theutonico, (quod) Maydburgense dicitur, locandi omnimodam potestatem.

Tłumaczenie na język polski:

My, Kazimierz, król Polski, informujemy wszystkich, tak tu obecnych, jak i potomnych, którzy to pismo będą czytać, że pragniemy, aby nasze królestwo jak najlepiej korzystało z lasów, z których dotąd nie było należytego pożytku, dlatego, zaufanemu Janowi z Biecza, dajemy wszelaką [pełną] władzę, aby wieś przy rzece zwanej Sczitnicza, lokował [zorganizował] na prawie niemieckim, nazywanym magdeburskim?

Budzi zdziwienie fakt, że wydawca i historycy, nawet najświeższej daty, nie przestudiowali dokładnie całej treści tego dokumentu. Czyżby zasugerowali się lokacją Rzepiennika w 1347 r. i w Moszczenicy w 1348 r., które otrzymały nazwę od nazwy rzek, przez nie płynacych? Ale dokumenty lokacyjne tych wsi nadawały im nazwy, a w naszym wypadku nie pojawia się nazwa wsi.

Dokument należy przestudiować w całości, do końca. Dla ułatwienia podaję zasadniczy fragment wyjaśniający, który się znajduje w połowie naszego dokumentu:

Nos Kazimirus,...rex Poloniae...removemus namque omnia iura Polonicalia”... Excipimus tamen, quod scultetus, et posteri ipsius, ad quamlibet expedicionem generalem servire in equo competenti tenebitur.

czyli:

My król Polski, informujemy wszystkich zainteresowanych, że...odwołujemy wszystkie normy prawa polskiego..., z wyjątkiem obowiązku soltysa, do uczestniczenia w każdej generalnej wyprawie[zbrojnej], na koniu dobrze wyekwipowanym.

Tak było w prawie polskim. Dzięki temu tekstowi dowiadujemy się, że przed 1351 r., ,,przy rzece Sczitniczy” istniała już wieś, królewska, osadzona, zorganizowana, na prawie polskim, dobrze znana królowi, świadkom i zasadźcy, dlatego wystarczała im informacja „wieś przy rzece Sczitnicza”. Jak się nazywała?

Redaktorzy tekstu i świadkowie zapewne wiedzieli, że ta wieś przy tej samej rzece nie utożsamia się z inną, istniejącą także przy rzece „Sczitnicza”, od wschodu granicząca z Bieczem oraz ze wsią niemiecką, „lokowaną” 23 czerwca 1348 r. na prawie niemieckim, a od zachodu z Rzepiennikiem. Ale dlaczego $\mathrm{w}$ dokumencie nas interesującym nie podano nazwy wioski istniejącej na prawie polskim, a tylko posłużono się określeniem: „przy rzece Sczitnicza”? Dla króla,

\footnotetext{
${ }^{7}$ Tamże, s. 81.
} 
świadków i zasadźcy, to określenie było jasne, oni wiedzieli o jaką wieś chodzi, ale nie późniejsze pokolenia.

Rozglądając się po licznych wsiach zorganizowanych na prawie magdeburskim, zwłaszcza za Kazimierza Wielkiego, stwierdzimy, że przed omawianym tu dokumentem z 30 września 1351 r., miały miejsce liczne lokaty nowych wiosek w około doliny rzeki Sczitniczy (obecnie Sitniczanki), albo przeniesienie starych wiosek z prawa polskiego na magdeburskie, a więc Szerzyny (1348 r.), Ołpiny, Górne i Dolne (1349 r.), Rzepiennik (1344 r. i 1347 r.), Ciężkowice miasto (1348 r.), Turza (1348 r.), Moszczenica (1348 r.). Miejsce na pozostałą część Nemsyna, który znajdował się środku, miedzy wyliczonymi wsiami, a więc, ,przy rzece Sczitniczy”, przy górnym jej biegu. Gdyż przy dolnym jej biegu, obok Biecza, była lokowana 23 czerwca 1348 r., też anonimowa wioska, później nazwana Binarową. A jak nazywała się wieś przy górnym biegu rzeki Sczitnicza, ,przy rzece Sczitniczy”, której dotyczył dokument lokacyjny z 30 września 1351 r.? Odpowiedź na to pytanie starają się dać dalsze analizy, zwłaszcza królewskiego przywileju restytucyjnego z 19 maja $1354 \mathrm{r}$.

Oto istotny jego fragment: „Król Kazimierz Wielki postanawia ....w imię szlachetności, jaka władcom przystoi”, zwraca biskupowi Bodzancie wsie jakie jego poprzednicy zabrali diecezji krakowskiej, a mianowicie:

Casimirus rex Poloniae...villas episcopales... scilicet: Radlow, Uswam, Besadky, Zawada, Przedsczicza, Iodlowa, Paseczna, Nemsyno in qua hereditate locate sunt due villae, videlicet Rzepennyk et Rosumberk, Cunow et Bucove, venerabili Patri, domino Bodzenthe, Episcopo et Ecclesiae Cracoviensi restituimus ex integro.

czyli:

My, Kazimierz, król Polski, następujące wsie: Radłów, Uszew, Biesiadki, Zawada Wielka, Przeczyca, Jodłowa, Pasieczna, Nemsyno, naszą własność dziedziczną, w której zostały lokowane dwie wsie, czyli Rzepennyk i Rosumberk, oraz Kumowa i Bukowa ... zwracamy wszystkie, Czcigodnemu Ojcu, Panu Bodzenthe, Biskupowi i Kościołowi Krakowskiemu8.

Dla nas istotne są następujące ,słowa-klucz”: [villa] „Nemsyno, in qua hereditate locate sunt due villae, videlicet Rzepennyk et Rosumberk", czyli; „z dziedzicznego, królewskiego, Nemsyna zostały założone dwie wioski: Rzepennyk i Rosumberk". Nemsyno było wielką wsią królewską, od rzeki Białej (wpadającej do Dunajca), ciągnęła się na wschód aż do granic Biecza i Binarowej. W zachodniej jej części, pokrytej wielkimi lasami, król Kazimierz założył dwa Rzepienniki, a we wschodniej jej części, w górnym dorzeczu Sczitniczy, tej „przy rzece Sczitnicza”, znajdowała się wieś, nienazwana przez dokument królewski

${ }^{8}$ Kodeks dyplomatyczny katedry krakowskiej św. Wacława. Część pierwsza (Monumenta Medii Aevi Historica Res Gestas Poloniae Illustrantia, T. I), ed. Franciszek Piekosiński, Kraków 1874, s. 252; C. Juruś, W gminie Biecz. Rożnowice-Racławice. Legendy i fakty, Racławice 2012, s. 8, pisze, że król Kazimierz Wielki dokumentem z 19 maja 1354 r. założył wieś Rosinberk [Rosumberk]. A król, wyliczając wioski zwracane biskupowi Bodzancie, dodał, że wsie Rosumberk i Rzepiennik „zostały założone” wcześniej, przed przywilejem z 1354 r., a nie tym przywilejem; Kozieł, Monografia Rożnowic, s. 22. 
z 30 września 1351 r. Tekst dokumentu z 9 maja 1354 r., przytoczony wyżej rozwiązuje problem, ponieważ informuje, że z pozostałej części wielkiej wsi, jaką było Nemsyno, została utworzona, zasadzona, wieś nazwana Rosumberkiem, a ten Rosumberk od początku był ,przy rzece Sczitnicza”. Przywilej królewski na tę lokację został wydany przez Kazimierza Wielkiego właśnie 30 września 1351 r. Dlaczego dokument królewski tego nie napisał, że „przy rzece Sczitniczy” była wieś Nemsyno? Postąpił podobnie jak w dokumencie dla wsi Binarowa, lokowanej 23 czerwca 1348 r., przy dolnej części tej samej rzeki. Niemniej, jest faktem, że od 30 września 1351 r., Nemsyno, początkowo polska wieś, przestała istnieć w wyniku przeniesienia jej z prawa polskiego na magdeburskie i zmiany nazwy na niemiecką, na Rosumberk, stale przylegający do górnego biegu Sczitniczy.

Król Kazimierz Wielki często powtarzał w dokumentach lokacyjnych, że z posiadanych wielkich lasów, on i kraj, nie mają prawie żadnego pożytku. Dlatego bardzo popierał zakładanie wsi przez polską ludność i zasadzenia, do lokacji, także w lasach królewskich. W kontekście tej polityki założył dwa Rzepienniki w lasach obejmujących rzekę Rzepiennik (obecnie: Rzepianka). Pierwszą lokację, zasadzenie, podpisał 6 października $1344 \mathrm{r}$. Tym dokumentem upoważnił Staszka i Pawła na założenie wsi ,in cruda radice”, „na surowym korzeniu”, przy rzece Rzepiennik, nadając tej nowej wsi nazwę „Rzepiennik”. Ta nowa wieś, założona na 100 łanach frankońskich, została zobowiązana do funkcjonowania na prawie magdeburskim. Oryginał przywileju założycielskiego i kopia zaginęły. Streszczenie oryginału czy kopii znajdujące się w dekrecie komisarzy, oblatowanym 20 października 1586 r. do Castrensia Sandecensia, zawiera krótki opis uposażenia9 . W następnych latach ten Rzepiennik otrzymał przydomek „Marciszewski”"10.

Druga lokacja Rzepiennika, według powyższych komisarzy nazwanego „Superior Rzepiennik”, czyli „Rzepiennik Górny”, nastąpiła 2 stycznia 1347 r. W niej zasadźcami zostali Paweł i jego synowiec Mikołaj. Tym razem wielkość lokowanej wsi Rzepiennik została ograniczona do 60 łanów. Uposażenie sołtysa stanowiły dwa łany, a wieś mogła posiadać dwa młyny, browar, ubojnię, piekarnię, pracownię szewską; każdy szósty denar czynszu i każdy trzeci z opłaty sądowej należały do króla; sądownictwo ma funkcjonować zgodnie z prawem niemieckim. Zasadźcy mieli zorganizować karczowanie lasów królewskich, które winno przynosić królowi solidny dochód, a kolonizatorom dobre warunki do osiedlenia się ${ }^{11}$.

\footnotetext{
${ }^{9}$ Po tym dokumencie zachował się tylko dekret komisarzy, zawierający streszczenie, 20 października 1586 r. oblatowany do Castrensia Sandecensia w Archiwum Państwowym w Krakowie, t. 112, s. 772. Zob. S. Kuraś, Zbiór dokumentów małopolskich, Cz. IV, Wrocław 1969, nr 931, s. $81-82$, s. 772.

${ }^{10}$ S. Kuraś, Zbiór dokumentów małopolskich, Cz. IV, Wrocław 1969, nr 931, s. 81, nota 931/1. Wymienieni komisarze napisali, że Rzepiennik lokowany 2 stycznia 1347 r. otrzymał nazwę „Strzyżewski”. Natomiast Teki Grona Konserwatorów Galicji Zachodniej, T. I, Kraków 1900, s. 289-290, informują, że najpierw został założony Rzepiennik Biskupi, a w 1344 r. pierwszy Rzepiennik, Marciszewski. Zgodnie z dokumentem lokacyjnym z 2 stycznia 1347 r. Rzepiennik nie posiadał żadnych przymiotników. Mówi tylko o jednym Rzepienniku. Podzielenie tego Rzepiennika mogło nastąpić po 1354 r., pod koniec XIV w. Można to dostrzec także w artykule F. Sikory: Biecz, s. 72-82.

${ }^{11}$ Kuraś, Zbiór dokumentów matopolskich, Cz. I, Kraków 1962, s. 59-60, nr 47.
} 
S. Kuraś, wydawca tego dokumentu, napisał, że wieś ta później została nazwana Rzepiennikiem Strzyżewskim ${ }^{12}$.

Po tych lokacjach, wielka wieś Nemsyno bardzo zmalała. Wschodnia jej część, początkowo zasiedlona Polakami, która rządziła się prawem polskim, przyjmując w 1351 r. prawo magdeburskie i nazwę niemiecką, mając za sąsiadów Rzepienniki i Binarową, przestała istnieć. Pojawił się Rosumberg.

Wsią sąsiadującą z Nemsyno/Rosumbergiem od wschodu była Binarowa, powstała w procesie kolonizacji doliny rzek Wisłoki i Ropy, w pobliżu Biecza, nad rzeką Sczitniczą/Sitniczanką. Osadnictwo, głównie niemieckie, trwało tu co najmniej od połowy XIII wieku, po najeździe tatarskim w $1241 \mathrm{r}$. W tym procesie imigracyjnym, stare polskie wioski zaludniały się ludnością niemiecką, niejednokrotnie stanowiąc większość. Tak stało się z wsią obok Biecza, (położoną poniżej granic Biecza”- ,inferius metis Beijcz”), istniejącą na prawie polskim przy rzece Sitnicza. Po jej zasiedleniu ludnością niemiecką, król Kazimierz Wielki, dnia 23 czerwca 1348 r., dał Mikołajowi Vlosniczarowi i Hermannowi władzę lokowania jej na prawie niemieckim. W przywileju wioski nie było jej nazwy, ale tylko określenie jej położenia. Początkowo nadawano jej takie nazwy niemieckie jak: Bernhaw, Bernhow, Benihaw, Byenarowa, Bonarowa, Bynarowa i in. Dzisiejsza nazwa: Binarowa, ustaliła się dopiero od około 1363 r. i obowiązuje do dzisiaj, lekko spolszczona ${ }^{13}$. Powyższa data, to nie data osadzenia wioski „na surowym korzeniu"14, ale to pozwolenie na przeniesienie wioski istniejącej na prawie polskim, na prawo niemieckie. Słowa królewskiego przywileju wyraźnie o tym mówią: „removemusque a predicta villa omnia Jura Polonicalia”, czyli: usuwamy $\mathrm{z}$ tej wioski wszelkie przepisy prawa polskiego ${ }^{15}$.

Wioska Binarowa, była jednym licznych przykładów na wschód od rzeki Ropy, zmiany nazw zastanych wiosek, albo zakładania własnych, niemieckich,

${ }^{12}$ Tenże, Zbiór dokumentów małopolskich, Cz. I, s. 59 i przypis 1 i w regestrze przywileju z 2 stycznia 1347 r., przedstawionym komisarzom królewskim 20 października 1586 r., tamże, Cz. IV, nr 935, s. 85, sugeruje, że było to zasadzenie Rzepiennika Strzyżewskiego.

${ }_{13}$ Privilegium fundationis seu erectionis Villae Binarova, Cracoviae 23 Junii 1348 anno, w: Kodeks dyplomatyczny Polski, Tom trzeci, wyd. J. Bartoszewicz, Warszawa 1858, s. 220-222; J. Długosz, Katalogi biskupów krakowskich, wyd. i kom. J. Szymański (Pomniki dziejowe Polski), Seria II, t. X, cz. 2, Warszawa 1974; s. 183-185; Januszek-Sieradzka, Binarowa w XIV-XVI stuleciu, s. 10-15; Sikora, Binarowa, w: Stownik historyczno-geograficzny województwa krakowskiego w średniowieczu, Cz. I, oprac. Z. Leszczyńska-Skrętowa, F. Sikora, Wrocław 1980, s. 117-118.

${ }^{14}$ S. Sikora, Binarowa, w: Stownik historyczno-geograficzny województwa krakowskiego w średniowieczu, Cz. I, Wrocław 1980, s. 117, napisał: „Kazimierz W. poleca założyć nową wieś [tj. Binarową] na rzeką Sitnicą (dziś Sietniczanką), poniżej Biecza”. Ale ta wieś już istniała na prawie polskim.

${ }^{15}$ I w tym dokumencie, podpisanym przez króla w Krakowie 23 czerwca 1348 r. (Privilegium fundationis seu erectionis Villae Binarowa, Kodeks Dyplomatyczny Małopolski, T. 3, s. 21), historycy nie zauważyli następujących słów królewskich: „removemusque a predicta villa omnia Jura Polonicalia, angarias et preangarias qualescumque...", czyli: odwołujemy wszelkie normy prawa polskiego obowiązujące w tejże wsi, na przykład obowiązki do podwodów i przewożenia. Z tekstu wynika, że wioska istniała wcześniej, a przywilej królewski przenosi ją z prawa polskiego na prawo magdeburskie. A więc, nie było to założenie nowej wioski „na surowym korzeniu”. 
w ramach kolonizacji niemieckiej ${ }^{16}$, podobnie jak Nemsyno, wioska „przy rzece Sczitnicza", której poprzednią nazwę udało się ustalić.

Zmiana nazwy starej polskiej wsi Nemsyno na Rosumberk (a później także na Rosumberg, Rosumbark, Rosemberg, Rosenberg, Roszembark, ${ }^{17}$, świadczy o jej germanizacji. Być może żyjący tam Polacy, byli zwolennikami zachowania dotychczasowej nazwy Nemsyno, oprócz której istniały nazwy Nemcyno, Niemcyno!, Niemieścino...? Różnice zdań co do nowej, niemieckiej nazwy mogły spowodować pominięcie jej w dokumencie, podobnie jak w wypadku Binarowej. Zwyciężyli Niemcy i polską nazwę wsi Nemsyno zastąpiono nazwą Rosumberk, co nastąpiło być może zaraz po ogłoszeniu przywileju królewskiego z 30 września 1351 r., albo dopiero przed dokumentem restytucyjnym, sporządzonym 9 maja 1354 r. Inne nazwy funkcjonowały nadal, np. u Długosza - Rozumberg, a w XVII stuleciu jako Rozembark, by w 1947 r. spolszczyć ją na Rożnowice. Ludność już w XVI w. była spolszczona, ale Firsty, Firlity, Knyble, Hycnary, Lenarty, Olbrychy są do dzisiaj. Kiedy Niemcy w czasie drugiej wojny światowej szukali kandydatów na Volkslistę, nie znaleźli chętnych. Od kilku wieków mieszkańcy Nemsyna/Rosumberku byli już Polakami.

\section{Kościól i parafia w Nemsynie/Rosumberku}

Królewski dokument z 30 września 1351 r. przenoszący wieś ,„przy rzece Sczitniczy" (Nemsyno), z prawa polskiego na prawo magdeburskie, przeniósł równocześnie wszystkie budynki, urządzenia, mieszkańców, zwierzęta, jatki, stawy i kościół z parafią. W jednym momencie wszystko znalazło się w nowej wsi, nazwanej Rosumberkiem. W Nemsynie kościół już był, ale nie było młyna, więc król, w tym dokumencie, polecił zasadźcy, Janowi, jego wybudowanie. Wymieniony kościół w Nemsynie wybudował Jan Muskata, kiedy był biskupem krakowskim, czyli w latach 1294/1295-132018, o czym pisał Jan Długosz. Najprawdopo-

${ }^{16} \mathrm{~S}$. Kuraś, Osadnictwo i zagadnienia wiejskie w Gorlickiem do połowy XVI, w: „, Nad rzeka Ropa. [Cz. 3], Kraków 1968, s. 61-91; J. Rudnicki, Osadnictwo na prawie niemieckim w średniowiecznej Polsce, Kraków 2006; K. Rymut, Nazwy miejscowe dawnego powiatu bieckiego, Wrocław 1975; B. Czopek-Kopciuch, Adaptacje niemieckich nazw miejscowych w języku polskim, Kraków 1995; J. Luciński, Majątki ziemskie panujacego w Małopolsce do 1385 roku, „Prace Komisji Historycznej Poznańskiego Tow. Przyj. Nauk”, 19 (1965) z. 2, s. 41-44, 93-122; Gluchoniemcy, w: https://pl.wikipedia.org/wiki/G\%C5\%82uchoniemcy (dostęp: 30.03.2018); Januszek-Sieradzka, Binarowa, s. 11-12.

${ }^{17}$ Rozembark, w: Teka Grona Konserwatorów Galicyi Zachodniej. Tom I, Kraków 1900, s. 285.

${ }^{18}$ T. Nowicki, Muskata Jan, w: Encyklopedia Katolicka, t. 13, red. E. Gigilewicz, Lublin 2009, kol. 525-527, bibliogr.; Katalogi biskupów krakowskich, w: Pomniki dziejowe Polski. S. II, t. X, cz. 2, wyd. J. Szymański, Warszawa 1974, s. 183-184; P. Szczur, Biskupi krakowscy w Polsce piastowskiej, w: Katedra krakowska w Średniowieczu, red. J. Deranowska-Łukaszewska, K. Kuczman, Kraków 1996, s. 9-24; T. Pietras, Krwawy wilk z pastoratem. Biskup krakowski Jan Muskata, Warszawa 2001; J. Wyrozumski, Dzieje Kościoła krakowskiego od Jana Muskaty do Jana z Radliczyc, w: Kościół krakowski w Tysiącleciu, Kraków 2000, s. 69-99; tenże, Muskata Jan, w: Polski Stownik Biograficzny, t. 22, red. E. Rostworowski, Wrocław 1977, s. 291-299; J. Maciejewski, Czas i okoliczności objęcia rządów przez biskupa krakowskiego Jana Muskaty, „Studia Historyczne”, 43 (2000) z. 2, s. 315-326. 
dobniej było to przed 1303 r. Poniższe teksty świadczą, że już pod koniec XIII w. Biecz był miastem strategicznym, znaczącym państwowo i kościelnie, leżącym na ważnym trakcie handlowym na Węgry i do Krakowa ${ }^{19}$.

J. Długosz napisał, że Wacław król czeski, po koronacji na króla polskiego w 1295 r., wymienił Biecz razem z całym okręgiem (a więc i ze wsią Rozumberk) za biskupią wieś, Kamienicę, na której później założono Nowy Sącz. Oto interesujący nas tekst znajdujący się w Kodeksie dyplomatycznym katedry krakowskiej św. Wacława, t. I. s. 145:

1303, die 24. Mensis Martii, Pragae. Nos Venceslaus dei gracia Bohemiae et Poloniae rex, notum facimus universis..., quod venerabilis princeps noster, dominus Cracoviensis Episcopus, faciendo nobiscum commutationem hereditatis episcopalis in Caminicia, districtus Sandecensis, cum nostro castro Byecz, cum omnibus suis pertinentibus ius patronatus quod in ecclesia sancti Adalberti in bonis eisdem Episcopus Cracoviensis habere dignoscitur ab antiquo.

czyli:

1303, dnia 24 marca, Praga. My, Waclaw, z łaski Bożej król Czech i Polski, informujemy wszystkich, że Czcigodny Nasz Książe, Pan Biskup Krakowski, dokonując z Nami zamiany wsi Kamienica, dziedzicznej wsi biskupów krakowskich, w obwodzie nowo-sądeckim, z naszym zamkiem w Bieczu i należącym do niego okręgiem, rezerwuje sobie prawo patronatu do kościoła filialnego św. Małgorzaty i macierzystego, św. Wojciecha w Bieczu ${ }^{20}$.

Ponieważ Bieczem i jego rejonem po 1292 r., Węgry źle zarządzały, a następnie także benedyktyni tynieccy, Wacław włączył go do Polski, jako dobra królewskie. O tym wydarzeniu Długosz napisał w dziele: Katalogi biskupów krakowskich, po łacinie:

hoc uno gaudet episcopus Cracoviensis et solatur prerogative privilegio quod ecclesiam parochialem Corporis Christi in oppido Biecz et ecclesiam parochialem in villa Rozembergk, quae etiam erat de proprietate episcopali tamquam per eum fundatas et dotatas (...).

czyli:

W całej tej sprawie jedno cieszy biskupa krakowskiego, że obsadzanie i zarząd kościoła i parafii Bożego Ciała w Bieczu oraz obsadzanie i zarząd kościoła i parafii w Rozembergku, które zbudował i uposażył biskup Jan Muskata, należą do biskupów krakowskich ${ }^{21}$.

${ }^{19}$ A. Kłodziński, Biecz na przełomie XIII, XIV wieku, w: Biecz. Studia historyczne, s.116-123; Tadeusz Ślawski, Biecz. Zarys historyczno- krajoznawczy, Biecz 1996, s.10-11; E. Kozieł, Monografia Rożnowic, s. 23-24; S. Tomkiewicz, Powiat gorlicki, w: Teka Grona Konserwatorów Galicji Zachodniej, T. I, Kraków 1900, s. 285

${ }^{20}$ Kodeks dyplomatyczny Katedry Krakowskiej św. Wactawa. Cz. I, (Monumenta Medii Aevi Res Gestas Poloniae Illustrantia) ed. F. Piekosiński. Kraków 1874, s. 145 nr 111; J. Długosz, Annales seu Cronicae Incliti Regni Poloniae. Liber nonus, Varsaviae 1978, s. 21-22; A. Mruk, Ludność parafii Rożnowice w latach 1918-1939, Rzeszów 2009, s.10-11; J. Mruk, Kościót parafialny pw. Św. Andrzeja i św. Anny w Rożnowicach. Studium historyczno-zabytkowe obiektu, Rzeszów 2008, s. 8.

${ }^{21}$ J. Długosz, Liber beneficiorum, T. III Monasteria (Opera omnia, T. IX), a cura A. Przezdziecki, Cracoviae 1864, s. 467; tenże, Katalogi biskupów krakowskich (Pomniki Dziejowe Pol- 
Informacja podana przez Długosza, że „biskup Jan Muskata założył i uposażył kościoły parafialne, Bożego Ciała w Bieczu oraz we wsi Rozembergk", ale zwłaszcza słowa: „oraz we wsi Rozembergk”, budziły i jeszcze budzą krytyczne uwagi w stosunku do tego dokumentu (i podobnych) oraz pytanie czy to nie jakaś manipulacja albo falsyfikat. Przecież za czasów Muskaty nie było wsi „Rozembergk". Stąd pomawianie Długosza, ewentualnie kopistów, o przekręty lub o błędną korektę ${ }^{22}$. Trzeba sobie uświadomić, że od śmierci bpa Muskaty (1320 r.), do czasu pisania przez Długosza dzieł historycznych upłynęło już 150 lat, i więcej niż sto lat od przywileju królewskiego z 30 września 1351 r., po którym wieś Nemsyno została przemianowana na Rosumberk. W Bieczu i już w Rozumbergku (w Rosumberku), przynajmniej proboszczowie wiedzieli, że ich kościoły zbudował bp Muskata. O Nemsynie nikt (lub prawie nikt) nie wiedział, więc mówiono: „,ze w Rozembargku”. Jest możliwe, że Długosz wpisał pierwotną nazwę miejscowości, w której Muskata zbudował kościół, ale kopiści w miejsce Nemsyna wpisali Rozumberg, aktualne miejsce świątyni zbudowanej kiedyś, w nieznanej aktualnie miejscowości. Zresztą, może pospolicie mówiono, że bp Muskata zbudował kościół znajdujący się Rozumbergu, co było prawdą, a historycy powinni sobie dodać: kiedy Rosumberk, (Rozumbergk, Rozembark) był Nemsynem.

Podsumowując ten fragment tekstu trzeba powiedzieć w oparciu o przytoczone dokumenty, że dzisiejsze Rożnowice są spadkobiercami nie tylko Rosumberku, powstałego na mocy dokumentu królewskiego z 30 września 1351 r., ale także spadkobiercami starej polskiej wsi Nemsyno, istniejącej za czasów bpa krakowskiego J. Muskaty (1295-1320) i że ten biskup zbudował w niej kościół, uposażył go oraz ustanowił tam parafię pod koniec XIII w. lub na początku XIV, prawdopodobnie przed $1303 \mathrm{r}$.

ski, S. II, T. X, cz. 2), Warszawa 1974, s. 184; Teka Grona Konserwatorów Galicji Zachodniej, t. I, Kraków 1900, s. 285; S. Starowolski, Vitae episcoporum Cracoviensium, Cracoviae 1655, s. 75-76. - Nadgraniczny Biecz z okręgiem opanowali na krótko Węgrzy. Dzisiejsza Słowacja w tamtym czasie była częścią Węgier, jako Górne Węgry, graniczące z Polską. Ponieważ Węgrzy, a następnie benedyktyni nie dbali o ten region, Wacław II, król Czech i Polski od 1300 r. (od 1292 r. książę krakowski), włączył je do Polski, jako własność królewską. Po łacinie: „Venceslaus...rex Bohemiae et Poloniae acquirens sibi et regno suo velut male custoditum perpetuo vindicavit, nec illud multipliciter rogatus et sollicitus restituere voluit et ab illo tempore in sortem regalem Castrum et oppidum Byecz cum suo districtu transit. Ex tanto damno (...) hoc uno gaudet episcopus Cracoviensis et solatur prerogative privilegio quod ecclesiam parochialem Corporis Christi in oppido Biecz et ecclesiam parochialem in villa Rozembergk, quae etiam erat de proprietate episcopali tamquam per eum fundatas et dotatas (...)". Zob. J. Długosz, Katalogi biskupów krakowskich, s. 184.

${ }^{22}$ Katalogi biskupów krakowskich i Libri beneficiorum, były przepisywane i kopiści mogli, jak twierdzi S. Kuraś, coś dodać, uzupełnić, zmienić, ale o większe błędy trudno ich pomawiać. W sprawie kopiowania Liber Beneficiorum i korekt warto zajrzeć do pracy S. Kurasia, Regestrum Ecclesiae Cracoviensis. Studium nad powstaniem tzw. Liber Beneficiorum Jana Dtugosza, Warszawa 1966, s. 5-10. 


\section{Johann z Biecza i Rozembarscy}

Zasadźcą, założycielem Rosumberku i pierwszym sołtysem, był Johann de Byecz, Jan z Biecza, biecki mieszczanin. Był on zaufanym króla Kazimierza Wielkiego, ,discretus”, dziedzicznym sołtysem Rosumberka - „scultetus de Rosumberk". O jego dalszym życiu, o ewentualnej rodzinie i działalności nic nie wiemy. Była to jednak rodzina znana w Bieczu, skoro w 1369 r. bratankowie Jana, Mikołaj i Radost, dostali od króla sołectwo w Mszance, na południe od Moszczenicy ${ }^{23}$. W 1383 r., w sądownictwie bieckim występuje Jan, mieszczanin biecki jako „wójt prowincjonalny biecki”24. O powiązaniach rodzinnych sołtysa Rosumbergku, Stiboriusa - Ścibora ${ }^{25}$, dowiadujemy się z zapisu w Aktach grodzkich i ziemskich z czasów Rzeczypospolitej Polskiej, w dokumencie z 1390 r. Jest tam zapisana ugoda między Małgorzatą, córką Ścibora, sołtysa wsi Rosenberg, żoną Piotra wójta w Krośnie, a jej ojcem, w sprawie przekazania jej części sołectwa rozembarskiego $\mathrm{w}$ ramach spadku ${ }^{26}$. Uszkodzony tekst, nie pozwolił na poprawne odczytanie nazwiska sołtysa, czy to Schoeneheyncz, a może Schultis, a taki w tym czasie w aktach bieckich występował. Małgorzata miała braci, i starała się i im zabezpieczyć prawo do podziału. Faktem jest, że podziały tego sołectwa rozpoczęły się już w 1390 r. powyższą ugodą.

Aleksander Włodarski w Rodzinie pisze, że w aktach krakowskich, w 1416 r., występuje Ścibor z „Rozenbarku” (i Rozembarku), herbu Nagody (Prus III) razem $\mathrm{z}$ synem Zygmuntem ${ }^{27}$. Po tej informacji wymieniony jest jeszcze Piotr, krewny, wnuk Ścibora?, występujący w aktach krakowskich w 1433 r. ${ }^{28}$

Tożsamość wymienionych Ściborów jest bardzo prawdopodobna, tym bardziej, że w życiorysie sławnego Mikołaja Rozembarskiego ${ }^{29}$, występuje Piotr,

${ }^{23}$ F. Sikora w haśle Biecz, w: Słownik historyczno-geograficzny województwa krakowskiego w średniowieczu, Cz. I, z. 1 A-Bobrek, s. 82, napisał, że król Kazimierz Wielki w 1369 r. przekazał braciom stryjecznym Jana z Biecza, Mikołajowi i Radestowi, sołectwo we wsi Mszanka, założonej 1364 r. Czyli ta rodzina była widoczna wśród mieszczan bieckich. W 1383 r. występuje „Jan mieszczanin biec. i wójt prowincjoanalny biec". Zob. Akta grodzkie i ziemskie z czasów Rzeczypospolitej Polskiej z Archiwum tak zwanego Bernardyńskiego we Lwowie, T. I, Lwów 1868, s. 8, dok VII. Czy był to Johann de Byecz, mianowany 30 września 1351 r. zasadźcą i sołtysem „wsi przy rzece Sczitniczy" (Rosumberk)? Prawdopodobne.

${ }^{24}$ Sikora, Biecz, w: Polski Stownik Biograficzny, t. 32, red. nacz. E. Rostworowski, Wrocław 1989-1991, s. 86.

${ }^{25}$ S. Tomkowicz, Powiat gorlicki, w: Teka Grona Konserwatorów Galicji Zachodnie, Kraków 1900, s 285. W dokumencie XXI, tamże, s. 28, w 1441 r., król Władysław Warneńczyk skazuje Jana, dziedzica Rozembergu, na wynagrodzenie szkód wyrządzonych Janowi z Lusławic.

${ }^{26}$ Akta grodzkie i ziemskie z czasów Rzeczypospolitej Polskiej z Archiwum tak zwanego Bernardyńskiego we Lwowie, T. I, Lwów 1868, s. 9, dok. VIII: umowa spadkowa.

${ }^{27}$ Rodzina. Herbarz szlachty polskiej. Ze zbiorów Seweryna Uhruskiego i Materiałów archiwalnych, oprac. A. Włodarski, t. 15, Warszawa 1931, s. 275, 277.

${ }^{28}$ Tamże, s. 277.

${ }^{29}$ K. Baczkowski, Rozembarski (Rosembarski, Rosenberski, Rosumberski, Mikołaj z Rozenberga) Mikołaj h. Jastrzębiec, w: Polski Stownik Biograficzny, t 32, red. nacz. E. Rostworowski, Wrocław 1989-1991, s. 384-388; Z. Kowalska, Mikołaja Rozembarskiego traktat z roku 1499 o pochodzeniu Tatarów, Kraków 1999. Na s. 9-19 znajduje się życiorys Rozembarskiego; I. Suł- 
jako ojciec tego Mikołaja. Autor życiorysu Mikołaja, Krzysztof Baczkowski, wymienia nie tylko żonę Piotra - Elżbietę, ale wspomina także jego dziadka, nie podając jego imienia. Mikołaj urodził się 1347 r.?, więc jego ojciec Piotr, około 1425 r., a dziadek Mikołaja około 1400 r. Kto był ojcem dziadka Mikołaja Rozembarskiego? Sam Ścibor, sołtys z Rozembarku, czy jego syn Zygmunt, a może inny syn Ścibora, np. Jan Rozembarski, herbu Jastrzębiec?

Jego urodziny przypadają na przełom XIV i XV w., gdyż w dokumentach urzędowych pojawia się w 1428 r. i 1441 r. jako dorosły człowiek, nazywając się: „Jan de Roszumbark de clenodio Jastrąbczow”, czyli Jan z Roszumbarku, herbu Jastrzębiec. W 1441 r. pojawia się ponownie w aktach sądowych króla Władysława Jagiellończyka, jako „Joannes de Rozemberg, heres”, czyli Jan dziedzic Rozembargu ${ }^{30}$. A zatem mógł być on synem sołtysa Ścibora, ojcem Piotra i „dziadkiem” Mikołaja? „Jan z Roszumbarku”, to heres, dziedzic, który nie kupował Rozembarku, ale go dziedziczył, albo współdziedziczył. W 1447 r. występuje również jako dzierżawca wsi i sołectwa w Rozembarku. Ścibor był sołtysem Rozembarku, herbu Nagoda, a Jan z „Roszumbarku”, był dziedzicem i szlachcicem herbu Jastrzębiec. Według T. Wojciechowskiego, to on otrzymał szlachectwo i dał początek rodu Rozembarskich, herbu Jestrzębiec, wywodzącego się od nazwy dziedzicznej wsi oraz sołtysostwa w Rozembergu ${ }^{31}$.

Przedsytawiona rekonstrukcja, jeżeli informacje Baczyńskiego, Wojciechowskiego i Włodarskiego są dokładne, daje zrąb genealogii rodu Rozembarskich. Jego częściowe uzupełnienie daje także pamięć rodowa Rozembarskich, zawarta w wypowiedziach powyższych autorów, którzy temu rodowi poświęcili więcej uwagi w życiorysach Mikołaja, sławnego przedstawiciela tego rodu.

Z życiorysu Mikołaja, o którym dalej, dowiadujemy się, że Rozembarg rozwijał się, skoro na jego terytorium powstały dwie nowe wioski: Sitnica i Racławice, a z nimi i problemy dziedziczenia: kogo i czym obdarzyć. W rodzie Rozembarskich jest to bardzo widoczne w drugiej połowie XV w., kiedy dzielono lub sprzedawano nawet całe sołectwo ${ }^{32}$.

\section{Mikołaj Rozembarski}

W 1465 r., pojawia się Mikołaj Rozembarski, h. Jastrzębiec, jako student na Uniwersytecie Krakowskim ${ }^{33}$. Po trzymaniu bakalaureatu, kontynuował prawdopodobnie studia we Włoszech, gdyż doskonale znał język włoski. Biegle posługiwał się także językiem niemieckim. Na dworze króla Kazimierza Jagiellończyka

kowska-Kurasiowa, Polska Kancelaria Królewska w latach 1447-1506, Kraków 1967, s. 30, 39, 48, 150, pozycja 142: Rozembarski Mikołaj, Rozumberski.

${ }^{30}$ Ulanowski Bolesław, Inscriptiones clenodiales (Starodawne prawa polskiego pomniki,) t. VII, s. 563; Akta grodzkie i ziemskie z czasów Rzeczypospolitej Polskiej z Archiwum tak zwanego Bernardyńskiego we Lwowie, T. II, Lwów 1870, s. 28.

${ }^{31}$ T. Wojciechowski, Bachmistrzostwo w Bochni, „Studia i materiały do dziejów żup solnych w Polsce", 14 (1985) s. 51-106

${ }^{32}$ Baczkowski, Rozembarski (Rosembarski, Rosenberski, Rosumberski, Mikołaj z Rozenberga), s. $384-387$.

${ }^{33}$ Tamże. 
pojawił się około 1480 r., nie tylko jako znany humanista, ale także jako dobrze zorientowany w problemach europejskich. Szczególnie zajmował się tureckim zagrożeniem Europy. Królowie: Kazimierz Jagiellończyk, a następnie Jan Olbracht, wysyłali go jako dyplomatę do krajów niemieckich, Fryburga, Kolonii, Augsburga, na sejmy Rzeszy Niemieckiej, do Gdańska w sprawach z zakonem krzyżackim, a także do Konstantynopola. Interesował się Sarmatami i ludami azjatyckimi. Sławna stała się jego mowa na sejmie Rzeszy we Fryburgu w 1498 r., znana jako Explanatio compendiosa de situ, moribus diversitate Scithicarum gentium - czyli Zwięzty wykład o kraju zamieszkałym przez ludy scytyjskie i ich zwyczajach ${ }^{34}$. Był także bachmistrzem, czyli specjalistą od spraw technicznych oraz budowy nowych żup bocheńskich.

K. Baczkowski interesował się również rodzinnym gniazdem Mikołaja, Rozembarkiem, gdzie ten wybudował sobie nowy, sołtysi dwór. Chociaż pod koniec XV w. mieszkał w Bochni, jako tamtejszy bachmistrz, to po śmierci ojca Piotra, sołtysa, ok. 1473 r., razem z bratem Janem, oraz ze siostrą, Katarzyną, zajmowali się sołectwem rozembarskim i sitnickim, które zostało utworzone w wyniku rozwoju wsi Rozembark. Pod koniec XV w. i na początku XVI w. sprzedawał je, zastawiał i odzyskiwał. K. Baczkowski; jego biogram rozpoczął słowami: „Mikolaj... pochodzil ...z drobnoszlacheckiej rodziny tenutariuszy i soltysów dziedzicznych wsi królewskich Rozembarku (dziś Rożnowice) i Sitnica”.

O sławnym Mikołaju Rozembarskim pisali także inni. Godne uwagi informacje o tym rodzie podaje również Teofil Wojciechowski, w artykule: Bachmistrzowstwo $w$ Bochni $^{35}$. Pisze w nim: że kolejnym nabywcą tego stanowiska w Bochni został Mikołaj Rozembarski, który, jak jego poprzednik, ojciec, Piotr, pochodzil z rodziny mieszczańskiej, która po nabyciu sołectwa we wsi Rożnowice pod Bieczem (dawniej Rozembargk), należącej najpierw do dóbr biskupstwa krakowskiego, a od Władysława Łokietka do królewszczyzn (konkretnie do starostwa bieckiego), została nobilitowana.

Na powiat biecki jako miejsce pochodzenia rodziny Mikołaja wskazuje także J. Sułowska-Kurasiowa w pracy poświęconej kancelarii królewskiej. Czyni to w dodatku do podstawowego tekstu pt.: Życiorysy personelu kancelarii królewskiej, na s. 150: „Rozembarski Mikołaj”. Tu pisze, ,że Mikołaj, sołtys rozembarski, pochodzi z powiatu bieckiego, z rodziny tenutariuszy i sołtysów wsi Rozembark ${ }^{36 "}$ ". Już wiemy z przywileju królewskiego z 30 września 1351 r., że Jan z Biecza był zarówno mieszczaninem bieckim, jak i pierwszym sołtysem w Rozembarskim. To pochodzenie i pierwsze sołectwo zostało zapamiętane przez kolejne pokolenia: Rozembarscy byli z Rozembarku.

Można jeszcze przyjrzeć się imionom sołtysów rozembarskich. K. Baczkowski i I. Sułkowska-Kurasiowa podają rodziców Mikołaja i jego rodzeństwo. Rodzicami byli Piotr i Elżbieta, a rodzeństwo stanowili: Mikołaj, Jan i trzy siostry. Autor życiorysu, Baczkowski, podał także dzieci Jana. Wcześnie pierwszym soł-

\footnotetext{
${ }^{34}$ Kowalska, Mikołaja Rozembarskiego traktat z roku 1499 o pochodzeniu Tatarów. Studium krytyczne. Kraków 1993. - Z. Kowalska zmieniła tytuł.

${ }^{35}$ Wojciechowski, Bachmistrzowstwo w Bochni, s. 51-106.

${ }^{36}$ Sułkowska-Kurasiowa, Polska Kancelaria Królewska, s. 150, poz. 142.
} 
tysem i właścicielem Rosumberkgu był Jan z Biecza w 1351 r., po nim - Ścibor, notowany w 1390 r., a dalej notowany w 1428 r., Jan, dziedzic - heres; w połowie XV w. Piotr „dziedzic”, od 1473 r.?, jego synowie Jan i Mikołaj, dziedzice. czyli co drugie pokolenie pojawia się Jan. Miał on czterech synów urodzonych po 1470 r., w tym Ścibora. Znana jest praktyka podtrzymywania w rodzie niektórych imion, a w przytoczonym wykazie widoczny jest Jan i Ścibor. Zwłaszcza imię Jan, uwiarygadnia domniemanie pochodzenia Rozembarskich od Jana z Biecza, sołtysa w Rozembarku.

Bezdzietny Mikołaj, dyplomata, był także pisarzem dworu królewskiego. Jemu, humaniście i historykowi, król Jan Olbracht polecił napisanie historii polskiej. Ponadto był bachmistrzem (ekspertem technicznym) żup bocheńskich i „barczimistrzem”, właścicielem wielkiej pasieki w „bieckich lasach”, zapewne w rozembarskich, w której zatrudniał swoją służbę i najętych robotników. To Mikołaj rozsławił ród Rozembarskich wystąpieniami dyplomatycznymi, historią ludów scytyjskich ${ }^{37}$. Zmarł $1506 \mathrm{r}$.

Analiza przestudiowanych źródeł pozwala na stwierdzenie, że głośny w XV-XVI stuleciach ród Rozembarskich, herbu Jastrzębiec, bardzo prawdopodobnie pochodzi od Jana/Johanna z Biecza, zasadźcy - założyciela wsi Rosumberkg na prawie niemieckim/magdeburskim, mieszczanina bieckiego i pierwszego sołtysa.

\section{Podsumowanie}

Wieś Rożnowice (Rosumberk, Rosenberg, Rozembark) została założona przywilejem (dokumentem) królewskim 30 września $1351 \mathrm{r}$. Na mocy tego dokumentu, sołtys, Jan z Biecza, usunął prawo polskie ze wsi królewskiej Nemsyno i zorganizował ją na prawie magdeburskim, a król nazwał Rosumberkiem. Ta nazwa ulegała małym modyfikacjom, ale od XVII stulecia wieś królewską nazywano Rozembarkiem, a od 1947 r. Rożnowicami. Jej zasadźcą na prawie magdeburskim, organizatorem i pierwszym sołtysem królewskiej wsi Rosumbark był Jan (Johann) z Biecza.

Kościół i parafia są dziełem bpa krakowskiego, Jana Muskaty (†1320 r), ustanowione na samym początku XIV wieku, przed 1303 r., a może wcześniej, po 1296 r.? W historii parafii Nemsyno-Rosumberk-Rozembark-Rożnowice, szczególne miejsce ma Mikołaj Rozembarski, rodak, sołtys, doradca królów, Kazimierza Jagiellończyka i Jana Olbrachta, dyplomata, znawca problemów tak niemieckich jak i tureckich; autor dzieł historycznych; posłował do Stambułu, do Kolonii, Augsburga, Fryburga.

${ }^{37}$ Baczkowski, Mikołaj, s. 384 i 386; Sikora, Biecz, w: Stownik historyczno-geograficzny województwa krakowskiego w Średniowieczu, s. 86; Archiwum Narodowe w Krakowie, Acta Castrensia Cracoviensia, t. 29, s. 40-44. W bartnictwie zatrudniał swoją służbę i robotników. 


\section{BIBLIOGRAFIA}

\section{Źródla rękopiśmienne}

Archiwum Kurii Metropolitalnej w Krakowie (AKMK)

Acta visitationis interioris 1595, 1602 i 1767

Archiwum Archidiecezjalne w Przemyślu (AAP)

Acta visitationis decanatus Biecensis ex anno ex anno 1767

Archiwum Narodowe w Krakowie

Acta Castrensia Cracoviensia, t. 29, s. 40-44

Acta Castrensia Sandecensia, t. 112, s. 772.

\section{Źródla drukowane}

Acta grodzkie i ziemskie z czasów Rzeczypospolitej Polskiej z Archiwum tak zwanego Bernardyńskiego, T. I, Lwów 1868, s. 9, dok. VIII.

Acta grodzkie i ziemskie z czasów Rzeczypospolitej Polskiej z Archiwum tak zwanego Bernardyńskiego, T. II, Lwów 1870, s. 28.

Kodeks Dyplomatyczny Małopolski [T. I] 1178-1386 (Monumenta Maedii Aevi Historica Res Gestas Poloniae Illustrantia. T. III), ed. Franciszek Piekosiński, Cracoviae 1876, s. XI-XII, 81-82.

Materiaty do historii miasta Biecza (1361-1632), oprac. F. Bujak, Kraków 1914.

Kodeks dyplomatyczny katedry krakowskiej św. Wacława. Część pierwsza (Monumenta Medii Aevi Historica Res Gestas Poloniae Illustrantia, T. 1), ed. Franciszek Piekosiński, Kraków 1874, nr CXCVIII, s. 252-254.

Kodeks dyplomatyczny Polski, T. 3, wyd. Julian Bartoszewski, Warszawa 1858, s. 220222.

Długosz Jan, Katalogi biskupów krakowskich (Pomniki dziejowe Polski, Seria II, t. X, cz. 2), wydał i komentarzem opatrzył J. Szymański, Warszawa 1974, 183-185.

Długosz Jan, Liber beneficiorum, T. III. Monasteria (Opera omnia, T. IX), a cura Aleksander Przezdziecki, Cracoviae 1864, s. 467.

Długosz Jan, Annales seu Cronicae Incliti Regni Poloniae. Liber nonus, Varsaviae 1978, s. 21-22.

Kuraś Stanisław, Zbiór dokumentów małopolskich, Cz. I, Kraków 1962, s. 81-82 nr 47; Cz. IV, Wrocław 1969, s. 81-82 nr 931, nota 931/1, nr 935, s. 85.

Starodawne prawa polskiego pomniki, T.VII, Inscriptiones clenodiales, zebrał Bolesław Ulanowski, Cracoviae 1882, s. 563.

Starowolski Szymon, Vitae episcoporum Cracoviensium, Cracoviae 1655, s. 75-76.

\section{Opracowania}

Baczkowski Krzysztof, Rozembarski (Rosembarski, Rosenberski, Rosumberski, Mikotaj z Rozenberga) Mikołaj h. Jastrzębiec, w: Polski Słownik Biograficzny, t. 32, red. E. Rostworowski, Wrocław 1989-1991, s. 384-388.

Barut Józef, Dawna ziemia biecka i jej stolica, w: Biecz. Studia historyczne, red. R. Kaleta, Wrocław 1963, 124-151.

Czopek-Kopciuch Barbara, Adaptacje niemieckich nazw miejscowych w języku polskim, Kraków 1995.

Dutka Czesław, Echo minionych dni Rzepiennika, Rzepiennik Suchy 1993.

Dutka Czesław Z dziejów Sitnicy, w: Sitnica wczoraj, dziś, jutro... Ku pamięci 660 lat, 120-lecia szkoły i Roku Kolbiańskiego, Sitnica 2011, s. 7-10. 
Fusek Witold, Biecz i ziemia biecka na tle swych legend, bajek, przesadów i zwyczajów, Biecz 1939.

Teka Grona Konserwatorów Galicji Zachodniej, T. I, Kraków 1900, s. 289-290.

Januszek-Sieradzka Agnieszka, Binarowa w CIV-XVI stuleciu, w: Binarowa. Studia i materiały z dziejów parafii i sanktuarium, red. W. Bielak, B. Walicki, S. Zych, Kolbuszowa 2011, s. 9-15.

Juruś Cecylia, Rożnowicko-racławickie legendy i fakty, Racławice 2009.

Juruś Cecylia, W gminie Biecz, Sitnica - legendy i fakty, Racławice 2016.

Kaczmarczyk Kazimierz, Monarchia Kazimierza Wielkiego. T. 2. Organizacja Kościoła, sztuka i nauka, Poznań 1946.

Kaleta Roman, Zamek w Bieczu, w: Studia historyczne, red. R. Kaleta, Wrocław 1963, s. 81-115.

Kiryk Feliks, Z dziejów miast zachodniej czesści Ziemi Bieckiej do 1520, w: Nad rzeka Ropa, Z dziejów Biecza, Gorlic i okolicy, [Cz. 3], red. J. Barut, S. Motyka, T. Ślawski, Kraków 1968, s. 155-200.

Kłodziński Adam, Biecz na przełomie XIII/XIV wieku, w: Biecz. Studia historyczne, red. R. Kaleta, Wrocław 1963, s. 116-123.

Kowalska Zofia, Mikołaja Rozembarskiego traktat z roku 1499 o pochodzeniu Tatarów, Kraków 1999; s. 9-19.

Kozieł E., Monografia Rożnowic, [b.m.w] 1965 (mps w posiadaniu autora).

Kuraś Stanisław, Osadnictwo i zagadnienia wiejskie w Gorlickiem do połowy XVI w., w: Z dziejów Biecza, Gorlic i okolicy, [Cz. 3], red. J. Barut, S. Motyka, T. Ślawski, Kraków 1968, s. 61-91.

Kuraś Stanisław, Regestrum Ecclesiae Cracoviensis. Studium nad powstaniem tzw. Liber beneficiorum Jana Dlugosza, Warszawa 1966, s. 5-10.

Luciński Jerzy, Majątki ziemskie panujacego w Małopolsce do 1385 roku. „Prace Komisji Historycznej Poznańskiego Tow. Przyjaciół Nauk”, 19 (1965) z. 2, s. 41-44.

Maciejewski Jacek, Czas i okoliczności objęcia rząów przez biskupa krakowskiego Jana Muskaty, „Studia Historyczne”, 43 (2000) z. 2, s. 315-326.

Mruk Agnieszka, Ludność parafii Rożnowicach w latach 1918-1939, Rzeszów 2009.

Mruk Jan, Kościót parafialny pw. Św. Andrzeja i Anny w Rożnowicach. Studium historyczno zabytkowe obiektu, Rzeszów 2008, mps.

Nowicki Tomasz, Muskata Jan, w: Encyklopedia Katolicka, t. 13, Lublin 2009, kol. 525527.

Pachowicz Władysław, Bractwo św. Anny w Rożnowicach, Gromnik 1954.

Pachowicz Władysław, Ksiądz Łukasz Forystek, Tarnów 1992

Pachowicz Władysław, Rożnowice. Szkice z dziejów parafii. Rzepiennik Suchy 2002.

Piekosiński Franciszek, O łanach w Polsce wieków średnich. Kraków 1887.

Pietras Tomasz, Krwawy wilk z pastorałem. Biskup krakowski. Jan Muskata, Warszawa 2001.

Rudnicki Jakub, Osadnictwo na prawie niemieckim w średniowiecznej Polsce, Kraków 2006.

Rymut Kazimierz, Nazwy miejscowe powiatu bieckiego. Wrocław 1975

Sikora Franciszek, Biecz, w: Słownik historyczno-geograficzny województwa krakowskiego wśredniowieczu, Cz. I, oprac. Z. Leszczyńska-Skrętowa, F. Sikora, Wrocław 1980.

Sułkowska-Kurasiowa Irena, Polska Kancelaria Królewska w latach 1447-1506, Kraków 1967, s. 150.

Szczur Piotr, Biskupi krakowscy w Polsce piastowskiej, w: Katedra krakowska w średniowieczu, red. J. Deranowska-Łukaszewska, K. Kuczman, Kraków 1996, s. 9-24. 
Szewczyk Janina, Wótka. Pojęcie i termin na tle innych średniowiecznych jednostek pomiaru ziemi. Warszawa 1968

Ślawski Tadeusz, Biecz. Zarys historyczno-krajoznawczy, Biecz 1996.

Ślawski Tadeusz, Biecz. Na jubileusz 2000-lecia, Biecz 1999-2000.

Ślawski Tadeusz, Biecz i okolice Biecza, Biecz 2005.

Ślawski Tadeusz, Biecz i dawna Ziemia Biecka, w: Nad rzeka Ropa, Z dziejów Biecza, Gorlic i okolicy, red. J. Barut, S. Motyka, T. Ślawski, Kraków 1963, s. 9-83.

Teka Grona Konserwatorów Galicji Zachodniej, T. I, Kraków 1900, s. 289-290.

Tomkiewicz Stanisław, Powiat gorlicki, w: Teka Grona Konserwatorów Galicji Zachodniej, T. I, Kraków 1900.

Wojciechowski Teofil, Bachmistrzostwo w Bochni, „Studia i materiały do dziejów żup solnych w Polsce", 14 (1985) s. 51-106.

Wyrozumski Jerzy, Dzieje Kościoła krakowskiego od Jana Muskaty do Jana z Radliczyc, w: Kościót krakowski w Tysiącleciu, Kraków 2000, s. 69-99.

Wyrozumski Jerzy, Muskata Jan, w: Polski Słownik Biograficzny, t. 22, red. E. Rostworowski, Wrocław 1977, s. 291-299.

Żaki Andrzej, Biecz i kasztelania biecka w zaraniu dziejów, w: Biecz. Studia historyczne, red. R. Kaleta, F. Błoński, Wrocław 1963, s. 34-63.

\section{Z SITNICY PRZEZ NEMSYNO, ROSUMBERK, ROZEMBARK DO ROŻNOWIC}

\section{Streszczenie}

Analiza królewskiego przywileju z 30 września 1351 upoważniającego Jana z Biecza do założenia wioski przy rzece Sczitniczy pozwoliła ustalić, że król Kazimierz Wielki nie upoważniał do założenia wioski Sitnicy, ale do przeniesienia wioski Nemsyno (także Niemcyno) z prawa polskiego na magdeburskie, która następnie otrzymała nazwę Rosumberk. W następnych stuleciach ta nazwa ulegała modyfikacji. Wioska była Rozumberkiem, Rosinbergiem, Rosenbergiem, od XVII w. Rozembarkiem, a od 1947 r. Rożnowicami. Sławnym dyplomatom i pisarzem politycznym na dworze królewskim był Mikołaj Rozembarski, herbu Jastrzębiec, ur. w Rozembergu ok. 1447 r., zm. w 1507 r.

Słowa kluczowe: Jan z Biecza; Nemsyno; sołectwo rozembarskie; Muskata Jan; Kazimierz Wielki; Długosz Jan; Rosumberk 1351 r.; osadnictwo niemieckie; prawo polskie; prawo magdeburskie 
FROM SITNICA THROUGH NEMSYNO, ROSUMBERK, ROZEMBARK TO ROŻNOWICE

\begin{abstract}
Summary
The analysis of the royal privilege of 30 September 1351 authorizing Jan of Biecz to found a village by the River Sczitnicza allowed the author to establish the fact that King Kazimierz Wielki did not authorize the man mentioned above to found the village but to change the village of Nemsyno (also Niemczno), founded on the Polish law, into the village with the German law. The settlement after this change was named Rosumberk. Over the next centuries, this name was modified; the village was called Rozumberk, Rosinberg, Rosenberg, Rozembark from the 17th century and Rożnowice from 1947. Mikołaj Rozembarski, born in Rozemberg about 1447, died in 1507, was a famous diplomat and a political writer at the royal court.
\end{abstract}

Keywords: Jan of Biecz; Nemsyno; the authorities of the village of Rozembark; Muskata Jan; Kazimierz Wielki; Jan Długosz; Rosumberk 1351; German settlement; the Polish law; the Magdeburg law 